\title{
Chapter 10 \\ Roma at School: A Look at the Past and the Present. The Case of Portugal
}

\author{
Lurdes Nicolau
}

\begin{abstract}
The schooling process has become more widespread among the Portuguese Roma population since 1974, with the end of the Estado Novo dictatorship and the establishment of democracy. Nevertheless, the Roma nomadism or seminomadism, financial shortcomings and the absence of social/cultural/family stimuli are some of the reasons that explain their low school attendance rates. Only in the last decades has such attendance increased, as a result of the implementation of several public policies, particularly of the Social Integration Income. This social policy, implemented in 1996, introduced important changes in this population, especially in areas such as schooling, personal hygiene, housing, health, or sedentism.

Recent research has shown an increase in the educational level of the Roma population, but school dropouts and failure remain high. This tendency was also studied in the northeast of Portugal, in a $\mathrm{PhD}$ thesis about the relationships between the Roma and school. In the present research work, a qualitative methodology was adopted, using direct and participant observation, as well as interviews to some Roma parents and non-Roma teachers. Both groups emphasize the main difficulties of Roma children at school.

The conclusions show that several factors affect these students' schooling nowadays, especially poor housing conditions, parents' illiteracy or low schooling, lack of daily study monitoring at home, absence of models in their environment, non-attendance of pre-school, and discrimination against them.
\end{abstract}

Keywords Roma $\cdot$ School $\cdot$ Education $\cdot$ Social policies $\cdot$ Northeast of Portugal

\footnotetext{
L. Nicolau (ه)

Centre for Research in Anthropology, NOVA FCSH Division, Lisbon, Portugal

(C) The Author(s) 2021

M. M. Mendes et al. (eds.), Social and Economic Vulnerability of Roma People, https://doi.org/10.1007/978-3-030-52588-0_10
} 


\section{Introduction}

Over the centuries, the Roma have suffered constant persecutions, as shown in several historical documents (Coelho [1892] 1995; Nunes 1996; Fraser 2005). In Portugal, this population was subject to forced nomadism (Bastos 2012), mostly living off begging and trading donkeys and mules (Alves 1982; Coelho [1892] 1995; Nunes 1996) until recently. Such factors have conditioned this population's relationship with school.

The presence of Portuguese Roma in schools started to be emphasized after the 1974 Revolution (Bastos 2007). However, the number of Roma children enrolled in state schools only increased significantly from the mid-1990s, mainly due to the implementation of the Social Integration Income in 1996.

This economic support measure brought about great changes within the Roma communities all over the country, namely regarding health, hygiene, housing, schooling, and sedentarism.

Despite the increase in the number of Roma children at school in Portugal, many difficulties have been observed regarding their educational path, attendance, attainment and integration (Bastos and Bastos 1999; AAVV 2001; Casa-Nova 2002; Bastos 2007; Mendes 2012; Lopes and Costa 2016).

This reality was also found in the northeast of the country, where a research work was conducted for a PhD thesis aiming to study the interethnic relationships between Roma and non-Roma in rural and urban settings, as well as in the school environment (Nicolau 2010). The empirical study was conducted in the municipality of Bragança, by means of a methodology which was essentially ethnographic, comprising direct and participant observation, as well as interviewing Roma and non-Roma population.

The aim of this research work is to bring to light the schooling situation of the Roma children, both at a national and regional level, as well as the reasons for their school failure, thus contributing to widen the existing knowledge of this issue.

The data presented in this article is based on a chapter of the above mentioned $\mathrm{PhD}$ thesis in social sciences (2010), which contains data regarding the school attainment, attendance and integration of the Roma children in the council of Bragança, but also intends to give voice to these pupils' parents and teachers in an attempt to understand the difficulties felt by both parties regarding these children's schooling process.

The results of the study reveal high rates of school absenteeism, dropout and failure, as well as several factors which negatively impact these pupils' educational path, among which are precarious housing, parents' illiteracy or low schooling, lack of daily study monitoring at home, absence of models in their environment, non-attendance of pre-school, and discrimination against them. 


\section{Roma at School: An Overview of the Past and the Present}

In the late nineteenth century, Adolfo Coelho ([1892] 1995) published an academic work on the Roma population in Portugal. It is a historical, ethnographic and linguistic work containing several legislative documents from the sixteenth to the nineteenth century, which make proof of expulsions, convictions, prohibitions and deportations which, as referred by the author, "could not make the Roma nor their inveterate customs disappear" (Coelho [1892] 1995, p. 239).

In the 1970s, Nunes (1996, p. 36) stated that there was a "marked contrast: on one side, the consumer society, increasingly more advanced technically and culturally, and on the other side, the more and more glaring Roma paralysis, enhancing their marginalization".

The majority society's persecution and discrimination towards the Roma is also emphasized in several studies conducted nationally wide (AAVV 2001; Bastos 2012; Magano 2012; Mendes 2012; Mendes et al. 2014), showing that they have been forced to nomadism, a situation which is still observed in the Alentejo region nowadays (Correia 2012).

In the northeast of the country, the local communities were wary of the Roma, and there are reports of persecutions and bans throughout time. Their main means of livelihood consisted of begging, exchanging services for food in rural communities, trading donkeys and mules, and doing some craftwork like basketry and pack saddle making (Alves 1982).

All the aforementioned aspects helped determine the interethnic relationships between the Roma and non-Roma, leading to their distancing from school since they arrived to our country, as their primary and main concerns were survival and subsistence.

The number of Roma pupils in Portuguese schools started to rise in the 1970s, and as stated by Bastos (2007, p. 42), this was mainly due to "a change in the mindset after the 1974 revolution, associated with the process of sedentarism and the extension of compulsory education to nine years".

However, despite the increase in the number of pupils in public schools, multiple reasons contributed to a moderate schooling process. We can highlight the following:

(i) The fact that the Roma children's education process was always conducted within the household, as "basic social, educational and economic unit" (AAVV 2001, p. 39), and that the parents "are wary of school and of its educational function, which might be disruptive to their culture" (AAVV 2001, p. 40);

(ii) Roma's nomadism, which according to Machado (1994, p. 58), "was highly stimulated by the persecution (or simply intolerance) which they suffered" as well as by the "rural impermeability", which hindered their sedentism and integration;

(iii) Financial shortcomings, since as stated by de Almeida et al. (1994, p. 57), it is from families "with lower incomes that the vast majority of pupils who drop out of school come"; 
(iv) The lack of stimuli within their social/cultural and family environment, since the high illiteracy in their milieu reflects on their disinterest in children's schooling;

(v) Their generalized conviction that school does not give them any advantage for entering the labour market (Nicolau 2010).

In a study on the various ethnic minorities residing in national territory, Bastos and Bastos (1999, p. 62) claim that the Roma's situation "was a lot worse than that of the immigrant ethnic minorities entering Portugal since the 1970s, in all the indicators available (living conditions, literacy, school failure and early dropout, imprisonment rates)."

The same authors state that in face to Roma the Portuguese reveal the most serious and blatant racism and xenophobia recorded in Portugal (Bastos and Bastos 1999, p. 155).

Such reality is also expressed in a recent work by Mendes et al. (2014, p. 19), where the Roma population is stated as continuing to be highly excluded, "considered to be the poorest ethnic group, with the worst housing conditions and the lowest schooling rates, and the main target of racism and discrimination within modern societies."

In 2001, Costa (2001, p. 30) reported an improvement in Roma children's schooling, which the author considers progressive, though slow. However, she highlights that "compulsory education attendance, attainment and completion remain, in most cases, little more than a mirage."

Magano concluded that their educational levels "are low, working conditions are precarious, housing conditions are insalubrious or inadequate to the household type and size, some have chronic illnesses and many do not have any support from Social Security." (2012, p. 238-239).

In the view of Mendes (2012, p. 308), the Social Integration Income had positive effects on "the return and continuity of children, adolescents and adults at school", although the effectiveness of this measure remains flawed and limited.

Besides promoting Roma's schooling, this social measure, implemented in 1996, favoured other aspects of this population's life, through local services established in the Integration Programmes. With regard to health, personal hygiene and house sanitation, actions were taken for awareness raising and monitoring towards the improvement of Roma's conditions, also contributing to many families' sedentism.

Nevertheless, although some social and educational policies led to an increase in the number of Roma pupils in schools and to the improvement of families' living conditions, "most Roma continue to show low educational levels, high rates of school failure, dropout and illiteracy, and low indices of higher education graduates compared to the non-Roma" (Magano and Mendes 2016, p. 10-11).

Casa-Nova (2009, p. 179) found "very low educational levels when compared to the global Portuguese population" in a Roma community residing on the outskirts of Porto.

The data published by Bastos and Bastos (1999, p. 146) reveal that at the end of the fourth grade, i.e. primary school, the Roma children's school attainment rate is 
extremely lower $(55,4 \%)$ than that of all the other European, African, Asian or South-American socio-cultural groups living in Portugal.

According to Bastos and Bastos (1999, p. 147), this extremely low attainment rate is indicative of "the cultural shock experienced by the Roma child when starting school and by many teachers (despite relevant exceptions) when having these pupils in their classes."

Carneiro (1997, p. 41-42) puts forward various reasons to explain their school absenteeism and failure, namely: (1) families' nomadism and semi-nomadism, as well as their conditions of extreme poverty, incompatible with study routines; (2) the low predisposition to go to school due to long distances and lack of transportation; (3) parents' illiteracy and disinterest in their children attending school; (4) the poor hospitality experienced at school, the school environment and the fact that teachers see them as a hindrance to the normal functioning of their classes.

Magano et al. (2016, p. 5) also report that the highest rates of illiteracy and early dropout-before completing primary school-are still found among the Roma, despite the efforts made through some social and educational policies, namely the extension of compulsory education. The number of Roma people who complete the ninth grade, i.e. third cycle of Basic Education, is still minimal, and cases of Roma completing Secondary School or Higher Education are extremely rare.

Magano and Mendes (2016, p. 18) state that primary school teachers do not point out any major differences between Roma and non-Roma pupils regarding school attainment. However, in the fifth and sixth grades, i.e. elementary school, Roma pupils start skipping classes without teachers clearly understanding why, since the pupils are often to be found within the school premises. One of the main factors leading to school failure, and eventually to dropout, is absenteeism, oftentimes caused by the frustration felt by pupils for not understanding the contents of the subjects.

According to Magano et al. (2016, p. 6), the prevalence of these educational and life paths "largely depends on public policies and programmes, but also on other individual factors, the kind of support within the household, the presence of rolemodels, the importance of peers, and on institutional factors inherent to the functioning of state school."

Currently, the Roma population's perspective towards school has somewhat changed, as the completion of primary school is a generalized phenomenon among younger generations and the increase of attendance rates in nursery, kindergarten and academic support lessons seems to have become a reality (Magano and Mendes 2016, p. 22). 


\section{Roma and School in the Northeast of Portugal}

The study of the Roma population in the northeast of Portugal stemmed from the research conducted for the aforementioned $\mathrm{PhD}$ thesis, which aimed to assess the interethnic relationships between the Roma and non-Roma in rural and urban settings, as well as the educational situation of Roma children (Nicolau 2010).

The non-existence of scientific research works on this ethnic group in the region of Trás-os-Montes and the shortage of studies on rural Roma triggered a need for the production of scientific knowledge which would bring to light an unstudied reality, thus contributing to widen the existing knowledge of the Roma in Portugal.

The study was conducted both in rural and urban areas in the council of Bragança, involving a total of 170 sample subjects living in six villages and a total of 85 sample subjects living in three neighbourhoods in the city of Bragança. Despite the existence of other Roma families living in villages or neighbourhoods within the municipality, these specific settings were chosen for the conduction of the study because of the significant number of Roma subjects living in these particular places.

As far as methodology is concerned, the work was conducted by means of a set of specific and diverse research techniques, which were appropriately combined so as to enable analysing and understanding the reality under study.

A thorough data collection took place in Bragança archives such as those of the Town Hall and local newspapers.

In total, 75 interviews were conducted, 30 of which to Roma individuals and the remaining 45 to non-Roma subjects (teachers, parish councillors, priests, employers, neighbours, among others).

Direct and participant observation took place in the three neighbourhoods in the city over a period of one year and in the six villages of the council over a period of 6 months.

Surveys by questionnaire were also used to obtain data regarding Roma children's schooling path, as well as photographs, maps and census of the Roma and non-Roma populations, from both the urban and rural areas.

With regard to the data collected concerning the school setting, we will start by giving the numbers of Roma pupils enrolled in the different educational levels in the whole municipality of Bragança. Subsequently, we will present the data regarding the school attainment/failure, absenteeism and dropout of the Roma children enrolled in primary school in the rural and urban settings where the empirical study was conducted, totalising a number of 53 children. Furthermore, we will list the difficulties regarding Roma children's schooling, according to the testimonies obtained from these pupils' teachers and parents.

Table 10.1 contains the total number of Roma pupils enrolled in the different educational levels in the municipality of Bragança in the school year of 2005/2006.

The data presented above shows that the vast majority of Roma pupils in Bragança council were enrolled in primary school. Also, there is a significant decrease in the number of pupils as the educational level increases. The number of pupils in pre-school is also exponentially lower than in primary school. Eleven 
Table 10.1 Gypsy students, attending public schools, in the municipality of Bragança 2005/2006

\begin{tabular}{|c|c|c|c|c|c|c|c|}
\hline $\begin{array}{l}\text { Pre- } \\
\text { primary } \\
(3-5 \\
\text { years } \\
\text { old) }\end{array}$ & $\begin{array}{l}\text { Primary } \\
(6-9 \\
\text { years } \\
\text { old })\end{array}$ & $\begin{array}{l}\text { Elementary } \\
(10-12 \\
\text { years old })\end{array}$ & $\begin{array}{l}\text { Elementary } \\
(13-15 \\
\text { years old })\end{array}$ & $\begin{array}{l}\text { Secondary } \\
\text { (16 years } \\
\text { old) }\end{array}$ & Technical & University & Total \\
\hline 13 & 84 & 18 & 19 & 3 & 2 & 2 & 141 \\
\hline
\end{tabular}

Source: Nicolau (2010), P.249

children attended kindergarten in several villages in the rural setting while only two siblings attended kindergarten in the city.

However, it should be said that years later (2009/2010), this situation had changed, with an increase recorded in the number of pupils attending pre-school in the urban setting. This was due to several factors, among which some delegations included in the Integration Programmes, all within the Social Integration Income policy.

The trend recorded in 2005/2006 is in line with those recorded in other settings nationwide, according to data published by Bastos and Bastos (1999, p. 142), obtained from the database Entreculturas. Such data showed that in Portugal, there was a sharp decrease in the number of Roma pupils attending pre-school and higher education when compared to the number of Roma children in primary school.

As far as school attainment is concerned, the chart in Fig. 10.1 shows the data regarding the 53 sample subjects of our study enrolled in primary school in the 2005/ 2006 school year.

According to the data presented, at the end of the 2005/2006 school year, among the 53 sample subjects enrolled in primary education, $29(55 \%)$ passed the year they were in, while $24(45 \%)$ failed, which represents a high percentage of school failure. Among these 24 children, 11 did not manage to achieve positive outcomes in their learning, and 13 were not evaluated due to a lack of evaluation elements. About these, the information provided by the teachers was that eight had dropped out and their whereabouts were unknown, and the other five were cases of school

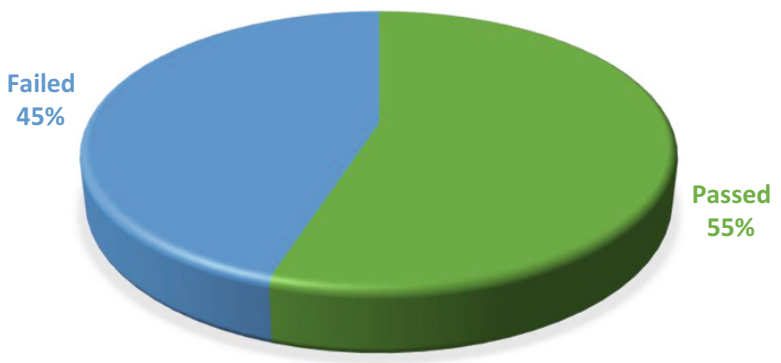

Fig. 10.1 Roma pupils' school attainment/failure in the northeast of Portugal, 2005/2006. Source: Nicolau (2010), p. 258 
absenteeism, having the children missed one of the three school terms. These were cases in which the families moved on a seasonal basis, either to Spain or to other regions in Portugal, to perform agricultural jobs, moving back to their permanent residence when such seasonal jobs ran out.

Data obtained on the non-Roma population attending primary school in the municipality in the school year of 2003/2004 showed that there were 1103 pupils enrolled and that among these, there were 42 cases (4.0\%) of school failures and 19 cases (1.7\%) of school dropouts (Câmara Municipal de Bragança 2006, p. 37). Therefore, when compared, the data shows that school failure and dropout are exponentially higher among the Roma population than among the non-Roma.

In light of this, the conclusion drawn is that the data obtained for the regional context is in line with the reality described nationwide regarding both the number of Roma Pupils enrolled in each educational level and the rates of school absenteeism, dropout and failure.

In order to assess the reasons for such numbers and the main difficulties related to Roma pupils' schooling, interviews were conducted with Roma parents and also with the teachers working in the educational institutions inserted in both the rural and urban settings where the empirical research was carried out.

By interviewing the parents, we intended to know their opinion regarding the school environment which was part of their children's daily life, the practices and activities held there, and the difficulties faced within the institution. By interviewing the teachers, we aimed to assess the difficulties felt daily when teaching these pupils, the rapport established with parents/guardians, and to understand how the Roma pupils socialize in the school setting.

According to the teachers interviewed, the main struggles when teaching Roma pupils were: (1) the fact that they had not attended pre-school, which hindered the acquisition of basic skills that might improve their performance when starting primary school; (2) the pupils' underachievement, due to their low motivation levels and the lack of support and monitoring of their school life by their families; (3) the low participation of parents in the school dynamics, generally only going to the school when asked to collect the pupils' end-of-term evaluation report; (4) the poor hygiene of some families, which led to the rejection/distancing by other pupils. This situation stemmed from the families' poor housing conditions and household sanitation, as most of these pupils lived in very run-down houses or shanties, oftentimes without a bathroom.

On the other hand, when interviewed, the Roma parents' referred the following: (1) Roma children's schooling is necessary, but it is enough for them to learn to read and write, since literacy is an asset for "getting a driving licence", "reading road signs", or "reading the mail", so attending primary school is enough as it is when children learn the desired skills; (2) the precarious housing conditions contribute to worsen the humiliation suffered at the hands of the whole school community, which created an unpropitious atmosphere to the children's wellbeing and learning, potentially leading to their demotivation and dropout; (3) The discrimination which, in their opinion, still prevailed, especially in the city schools, where teachers' attention was focused on the non-Roma pupils. 
When analysing the other educational levels, we can see from the data shown in Table 10.1 that after completing the fourth grade, the rates of school dropout are very high in the fifth and sixth grades and in the following levels. Such rates might be justified by a number of reasons, which may vary according to the pupils' gender.

Boys are allowed to continue their schooling if they wish so, but their dropout is mainly due to the following: a lack of support and monitoring within the household (family members are oftentimes illiterate or have a low educational level); the increasing complexity of the curriculum contents; financial shortcomings; prospects of an apprenticeship "near the adults"; a generalized idea that school does not bring them any advantage because discrimination prevails in society and they feel disadvantaged compared to the non-Roma when trying to enter the labour market; parents' inability to monitor their school life due to the distance between home and school; the inner family/group pressure of a dominant cultural pattern concerning the level of education that a Rom needs; the lack of successful schooled role-models within their community.

As far as girls are concerned, besides the aforementioned reasons, there is a family concern with the preservation of their virginity when reaching puberty, and the fear of a possible emotional or sexual involvement with non-Roma boys or with Roma boys from families which do not live up to the desired standards.

With regard to the non-attendance of pre-school education, the parents (1) considered that children were too young to stay away all day and might need their care; (2) revealed some fear towards non-Roma children and adults and other Roma children attending the same institution because their children did not have defence mechanisms in the event of unexpected situations such as fights; (3) viewed the four years of schooling in primary education as sufficient; (4) could perfectly look after their children since they did not have a stable job.

Despite all these reasons, fear was mostly reported in unknown settings and in the settings where the interethnic relations between the Roma and non-Roma were somewhat tense. In some villages in the rural setting, where the level of acceptance towards the Roma population was high, Roma children started their schooling process at the age of three, like any other child.

\section{Conclusions}

The aim of this work was to give an overview of the Roma population schooling situation in Portugal, especially of the reality observed in the northeast of the country, thus contributing to widen the existing knowledge of this issue.

Over the centuries, the Roma population has suffered numerous persecutions, a situation which currently prevails, since they are the most discriminated ethnic group (Bastos 2007). Such factors have contributed to their distancing from the education system.

Despite some progress, both nationwide and in the council under analysis, Roma children's schooling is still meagre, since school dropout and failure remain very 
high and the number of pupils who complete compulsory education, i.e. secondary school, remains low.

Various factors have contributed to the increase in the enrolment of these pupils in Portuguese schools. Among such factors is the implementation of some public policies, namely the introduction of the Social Integration Income.

According to teachers, the main difficulties felt in the schooling of these pupils lay in their non-attendance of pre-school, the lack of monitoring by their parents, parents' disinterest in school, and the fact that some pupils' poor hygiene kept other children away and led to discrimination issues.

From the Roma parents' point of view, children's schooling is necessary for a number of reasons. However, they considered learning to read and write to be enough for their offspring. Their poor housing conditions were believed to be a factor which negatively impacted children at school and contributed to the prevailing discrimination, especially in the schools located in urban areas.

Furthermore, other aspects contributing to Roma pupils' school failure include the lack of models, in other words, successful schooled people in their close community; the distance between home and school; and cultural aspects, mainly leading to girls' school dropout when they reach puberty and to feelings of fear when the relationships established with non-Roma are not trustworthy.

\section{References}

AAVV. (2001). Que Sorte, Ciganos na nossa Escola! Lisboa: Centre de Recherches Tsiganes/ Secretariado Entreculturas.

Alves, F. (1982). Memórias Arqueológico-Históricas do Distrito de Bragança ou Repositorio amplo de noticias chorographicas, hydro-orographicas, geologicas, mineralogicas, hydrologicas, bio-bibliographicas, hiraldicas, etymologicas, industriaes e estatisticas interessantes tanto á historia profana como ecclesiastica do districto de Bragança. Bragança: Tipografia Académica.

Bastos, J. G. (2007). Sintrenses Ciganos-Uma abordagem estrutural-dinâmica. Sintra: Câmara Municipal de Sintra/Divisão de Saúde e Acção Social.

Bastos, J. G. (Ed.). (2012). Portugueses Ciganos e Ciganofobia em Portugal. Lisboa: Edições Colibri/CEMME.

Bastos, J. G., \& Bastos, S. (1999). Portugal multicultural. Lisboa: Fim de Século Edições.

Câmara Municipal de Bragança (coord.). (2006). Carta Educativa do Concelho de Bragança. Bragança.

Carneiro, M. d. R. A. d. C. (coord.). (1997). Crianças de Risco. Lisboa: Instituto Superior de Ciências Sociais e Políticas.

Casa-Nova, M. J. (2002). Etnicidade, Género e Escolaridade-Estudo em torno das socializações familiares de género uma comunidade cigana da cidade do Porto. Lisboa: Instituto de Inovação Educacional.

Casa-Nova, M. J. (2009). Etnografia e Produção de Conhecimento: Reflexões Críticas a partir de uma Investigação com Ciganos Portugueses. Lisboa: Alto Comissariado para a Imigração e Diálogo Intercultural.

Coelho, A. [1892] (1995). Os ciganos de Portugal. Com um Estudo sobre o Calão. Lisboa: Publicações D. Quixote. 
Correia, A. C. (2012). “A gente não tem casa, é um dia aqui um dia além, somos ambulantes pronto!". A produção social do "nomadismo" cigano. In J. G. Bastos (Ed.) Portugueses Ciganos e Ciganofobia em Portugal (pp. 239-266). Lisboa: Edições Colibri/CEMME.

Costa, E. L. (2001). O Povo Cigano-memória histórica, presente e futuro. In AAVV. Que Sorte, Ciganos na nossa Escola! (pp. 15-31). Lisboa: Centre de Recherches Tsiganes/Secretariado Entreculturas.

de Almeida, J. F., et al. (1994). Exclusão Social: Factores e tipos de Pobreza em Portugal. Oeiras: Celta Editora.

Fraser, A. (2005). Los Gitanos. Barcelona: Editorial Ariel.

Lopes, D. S., \& Costa, A. R. (2016). Os ciganos de Lisboa e a escolarização: evoluções, impasses, dilemas (2003-2015). Configurações, 18, 67-86.

Machado, P. F. (1994). A presença cigana em Portugal: um caso de exclusão secular. Mediterrâneo, 4, 53-68.

Magano, O. (2012). Sentimentos de discriminação e racismo de ciganos portugueses In M. C. Silva \& J. M. Sobral (Eds.), Etnicidade, Nacionalismo e Racismo. Migrações, minorias étnicas e contextos escolares (pp. 235-253). Porto: Eduções Afrontamento.

Magano, O., \& Mendes, M. M. (2016). Constrangimentos e oportunidades para a continuidade e sucesso educativo das pessoas Ciganas em Portugal. Configurações, 18, 8-26.

Magano, O., Mendes, M. M., \& Gomes, S. (2016). Introdução-Ciganos e Educação. Configurações, 18, 5-7.

Mendes, M. M. (2012). Ciganos e escola. Contextos e eventos percepcionados como discriminatórios. In M. C. Silva \& J. M. Sobral (Eds.), Etnicidade, Nacionalismo e Racismo. Migrações, minorias étnicas e contextos escolares (pp. 301-313). Porto: Eduções Afrontamento.

Mendes, M. M., Magano, O., \& Candeias, P. (2014). Estudo Nacional sobre as comunidades ciganas. Lisboa: Ed. ACM, IP.

Nicolau, L. (2010). Ciganos e não Ciganos em Trás-os-Montes: Investigação de um Impasse interétnico. Chaves: UTAD (tese de doutoramento em Ciências Sociais).

Nunes, O. (1996). O Povo Cigano. Lisboa: Ed autor/Obra Nacional da Pastoral dos Ciganos.

Open Access This chapter is licensed under the terms of the Creative Commons Attribution 4.0 International License (http://creativecommons.org/licenses/by/4.0/), which permits use, sharing, adaptation, distribution and reproduction in any medium or format, as long as you give appropriate credit to the original author(s) and the source, provide a link to the Creative Commons licence and indicate if changes were made.

The images or other third party material in this chapter are included in the chapter's Creative Commons licence, unless indicated otherwise in a credit line to the material. If material is not included in the chapter's Creative Commons licence and your intended use is not permitted by statutory regulation or exceeds the permitted use, you will need to obtain permission directly from the copyright holder.

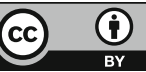

